\title{
IMPLEMENTASI PENDEKATAN PRAGMATIK DALAM PEMBELAJARAN KETERAMPILAN BERBICARA DI SEKOLAH
}

\author{
Muh. Jaelani Al-Pansori*
}

\begin{abstract}
This article is a theoretical study on the implementation of a pragmatic approach in learning speaking skills at school. Pragmatic approach is one of learning approaches that aims to train students to improve their speaking skills at school. This approach focuses on contextual learning speaking skills, particularly in the process of learning at school. Through this approach, students will be brought closer to practical conditions of speaking both orally and in writing. Thus, the learning skills of speaking with a pragmatic approach are very effective in creating active learning, especially in improving their speaking ability in the classroom and outside the classroom.
\end{abstract}

Keywords: pragmatic approach, speaking skills

\begin{abstract}
Abstrak
Artikel ini merupakan kajian teoretis tentang implementasi pendekatan pragmatik dalam pembelajaran keterampilan berbicara di Sekolah. Pendekatan pragmatik salah satu pendekatan pembelajaran yang bertujuan melatih siswa untuk meningkatkan keterampilan berbicara di sekolah. Pendekatan ini menitikberatkan pada pembelajaran keterampilan berbicara secara kontekstual, utamanya dalam proses pembelajran di Sekolah. Melalui pendekatan ini, peserta didik akan lebih didekatkan dengan kondisi praktis berbicara baik secara lisan maupun tulisan. Dengan demikian, pembelajaran keterampilan berbicara dengan pendekatan pragmatik ini sangat efektif dalam menciptakan pembelajaran yang aktif terutama dalam meningkatkan kemampuan berbicara siswa di dalam kelas maupun diluar kelas.
\end{abstract}

Kata kunci: pendekatan pragmatik, keterampilan berbicara

\section{A. Pendahuluan}

Pada hakikatnya, belajar bahasa adalah belajar berkomunikasi. Oleh karena itu, pembelajaran bahasa Indonesia di sekolah diarahkan untuk meningkatkan kemamapuan peserta didik dalam berkomunikasi, baik secara lisan maupun tulisan. Bahasa sebagai sarana komunikasi digunakan dalam bermacammacam fungsi dan disajikan dalam konteks yang bermakna, tidak dalam bentuk kalimat-kalimat lepas. Berdasarkan hal tersebut, perlulah kita mengkaji atau menelaah suatu pendekatan dalam pendidikan terutama dalam pembelajaran yang mengombinasikan kondisi atau tujuan tersebut.

\footnotetext{
* Muh. Jaelani Al-Pansori adalah Dosen STKIP Hamzanwadi Selong
} 
Orientasi belajar mengajar bahasa berdasarkan tugas dan fungsi berkomunikasi disebut pendekatan komunikatif (Nababan, 1987 : 71). Di dunia pengajaran bahasa istilah pragmatik yang identik dan digunakan silih berganti dengan istilah komunikatif digunakan untuk menyebut (1) kompetensi yang menjadi tujuan pengajaran, (2) fungsi yang menjadi bahan pengajaran, dan (3) faktor-faktor yang membatasi kompetensi dan fungsi yang diajarkan (Yohanes, 2006). Dari pendapat itu jelaslah bahwa pendekatan komukatif merupakan suatu alternatif solusi menghadapi kebutuhan atau tuntutan tersebut. Pendekatan komukatif mengacu pada fungsi bahasa sebagai alat komunikasi. Hal inilah yang akan menjadikan pembelajaran bahasa semakin komunikatif ketika didekati dengan cara-cara yang komunikatif.

Berorientasi pada suatu kemampuan komunikasi, pembelajaran bahasa juga dapat didekati melalui salah satu bidang kajian bahasa yaitu pragmatik. Pengajaran bahasa dengan pendekatan pragmatik lazim disebut dengan fungsi komunikatif dengan sejumlah fungsinya. Pragmatik merupakan suatu kajian bahasa dengan melibatkan berbagai aspek di luar bahasa yang mampu memberi makna. Gazdar (dalam Edi Subroto, 2011: 10) merumuskan bahwa pragmatik adalah studi arti minus kondisi benar. Kondisi benar yang dimaksud adalah arti yang menunjukkan benar berdasarkan arti kata-kata yang dipakai bersama aspek struktur dari tuturan itu. Dengan demikian pragmatik mengkaji aspek-aspek arti lainnya di luar arti leksikal kata yang dipakai bersama dengan arti struktural tuturan itu yang bersifat bebas konteks.

Kemampuan untuk mengkaji hal-hal di luar bahasa pastilah akan sangat membantu peserta didik (peserta didik) dalam mengaplikasikan kompetensi berbahasa yang dimilikinya secara praktis dalam kondisi senyatanya. Dengan pendekatan pragmatik dalam pembelajaran bahasa diharapkan peserta didik akan lebih dapat mengaktualisasikan kemampuan berbahasa yang dimiliki dalam kehidupan sehari-hari dalam masyarakat.

Berangkat dari hal-hal tersebut di atas, artikel ini merupakan kajian teoretis tentang penerapan pendekatan pragmatik di sekolah. Hal inilah yang akan menjadi kajian kritis dari sejumlah teori, sehingga dapat menghasilkan simpulan yang efektif.

\section{B. Pembahasan}

\section{Pragmatik dalam Pengajaran Bahasa}

Secara luas telah diketahui bahwa mutu pendidikan di Indonesia rendah. Dikaitkan dengan pendidikan dalam bidang bahasa, guru lebih banyak memeberikan teori dari pada memberikan kesempatan kepada peserta didik untuk mempraktikkan bahasa yang mereka pelajari. Guru lebih banyak mengajarkan tentang bahasa dan bukan bagaimana menggunakan bahasa yang baik dan benar. Setelah hal tersebut disadari kemudian muncul pendekatan baru dalam pengajaran bahasa, yang kita kenal dengan pendekatan komunikatif. Pendekatan komunikatif ini dilaksanakan melalui konsep baru yang disebut dengan pragmatik.

Sebelum mengkaji lebih jauh akan dipaparkan suatu pengertian dari pragmatik yang dikutip dari salah satu ahli bahasa. Levinson berpendapat bahwa pragmatik ialah kajian dari hubungan antara bahasa dan konteks yang mendasari penjelasan pengertian bahasa (Nababan, 1978 : 3). Dari pendapat tersebut terlihat 
bahwa pragmatik merupakaan salah satu bidang kajian bahasa yang melibatkan unsur-unsur di luar bahasa (konteks) di dalam pengkajiannya.

Dalam pragmatik, pengkajian bahasa didasarkan pada penggunaan bahasa bukan pada struktural semata. Konteks-konteks yang melingkupi suatu bahasa akan mendapat perhatian yang besar dalam kaitannya dengan makna yang muncul dari suatu penggunaan bahasa. Kondisi praktis tindak komunikasi menjadi pijakan utama dalam pengkajian pragmatik. Dalam hal ini, wacana-wacana yang berkaitan dengan proses komunikasi akan dikaji.

Menurut Maidar Arsyad (1997: 3.17), pragmatik membaca pengkajian bahasa lebih jauh ke dalam keterampilan menggunakan bahasa berkomunikasi praktis dalam segala situasi yang mendasari interaksi kebahasaan antara manusia sebagai anggota masyarakat. Pendapat tersebut memberikan penjelasan bahwa orientasi pragmatik adalah pada suatu komunikasi praktis, di mana pada tataran praktis muncul berbagai faktor di luar bahasa yang turut memberi makna dalam proses komunikasi tersebut. Adapun Nababan mengemukakan beberapa faktor penentu dalam komunikasi:

Siapa yang berbahasa;, dengan siapa; untuk tujuan apa, dalam situasi apa, (tempat dan waktu); dalam konteks apa (peserta lain, kebudayaan dan suasana); dangan jalur apa (lisan atau tulisan); media apa (tatap muka, telepon, surat, dan sebagainya); dalam peristiwa apa (bercakap-cakap, ceramah, upacara, laporan, dan sebagainya) (1987 : 70).

Dari pendapat tersebut didapatkan beberapa faktor yang mungkin sekali memepengaruhi proses tindak komunikasi yaitu pelaku, tujuan, situasi, konteks, jalur, media, dan peristiwa. Senada dengan Nababan, Suyono (1990 : 18) mengemukakan tiga konsep dasar dalam penggunaan bahasa (studi pragmatik) yaitu tindak komunikasi, peristiwa komunikasi dan situasi komunikasi (1990 : 18). Kedua pendapat tersebut tidak jauh berbeda, hanya saja Suyono lebih meringkas lagi faktor-faktor penentu tersebut dalam tiga konsep dasar.

Dengan berpijak pada beberapa hal di atas, jelaslah bahwa pragmatik sangat membantu dalam pengajaran bahasa khususnya di sekolah. pengajaran bahasa yang berorientasi pada kajian bahasa secara "struktural" jelas akan menimbulkan banyak kendala ketika tidak dikaitkan dengan penggunaan bahasa secara praktis di lapangan. Dalam kegiatan berbahasa seseorang dituntut untuk mencapai kualitas yang bersifat pragmatis. Dengan bentuknya yang pragmatis diharapkan peserta didik dapat menggunakan bahasa sasaran sesuai konteks yang melatari kegiatan bahasa nyata (Nurhadi, 1995:146). Dari pendapat tersebut, komunikasi yang terjadi diorientasikan pada pencapaian kualitas yang bersifat pragmatis, sehingga peserta didik dapat menggunakan bahasa sesuai dengan konteksnya.

Pembelajaran bahasa sudah semestinya mampu mengakomodasi kebutuhan berbahasa secara praktis sesuai dengan kondisi yang nyata. Dengan pola yang berdasar pada kajian pragmatis, proses pembelajaran bahasa yang diterima oleh peserta didik secara otomatis akan mengacu pada suatu kondisi praktis tindak komunikasi. Orientasi pembelajaran yang seperti ini, akan menuntut penyesuaian pada berbagai aspek pembelajaran dari kurikulum sampai tataran praktis pembelajaran. Seperti dikemukakan oleh Maidar Arsyad (1997:317) ada 
tiga hal penting dari pendapat tersebut, yaitu program belajar, ragam bahasa, dan pelatihan sesuai situasi dan konteks.

Tiga hal tersebut memang sangat penting ketika suatu pembelajaran bahasa sudah berorientasi pada penggunaan bahasa dalam tataran praktis. Penggunaan itu dapat dimulai dari program, materi (bahan), ragam bahasa, dan menciptakan suatu situasi dan konteks yang sesuai jelas tidak dapat dihindarkan ketika target akhir dari pembelajaran bahasa adalah "peserta didik mampu berkomunikasi secara efektif dan efisien sesuai dengan etika yang berlaku, baik secara lisan maupun tulis" (BSNP, 2006).

Ada juga berpendapat lain yang lebih jauh menambah aspek lain di luar bahasa, Eny (2004) berpendapat:

Pengajaran bahasa Indonesia seharusnya berdasarkan pada dimensi kultural karena dalam pembelajaran ini diungkapkan gagasan mengenai masalah yang berkaitan dengan ilmu, teknologi dan atau budaya yang sedang dipelajarinya. Pengajaran itu difokuskan pada kemahiran menggunakan bahasa yang benar, jelas, efektif, dan sesuai dengan fungsi bahasa sebagai alat komunikasi.

Pendapat Eny tersebut mencoba melibatkan dimensi kultural karena berkaitan dengan aspek-aspek kehidupan yang lain. memang suatu bahasa pada akhirnya akan bersinggunangan dengan berbagai aspek yang lain ketika manusia dalam menuangkan gagasan apapun akan menggunakan suatu bahasa. Jadi akan sangat berterima jika suatu pembelajaran bahasa harus berdasar pada kondisi praktis.

Berdasarkan berbagai paparan di atas, dapat disimpulkan bahwa pembelajaran bahasa yang diorientasikan pada tataran praktis tindak komunikasi akan sangat diperlukan bagi peserta didik. Dalam hal ini, pendekatan komunikatif (lebih spesifik pragmatik) sangat membantu dalam mengarahkan proses pembelajaran bahasa yang dilakukan, terutama dalam pendidikan formal atau sekolah.

\section{Kajian Kurikulum Kaitannya dengan Pendekatan Pragmatik}

Di Indonesia akhir-akhir ini terjadi perubahan kurikulum. Sampai saat ini yang sedang diberlakukan adalah Kurikulum Tingkat Satuan Pendidikan atau yang lebih dikenal dengan sebutan KTSP. KTSP ini merupakan aplikasi lebih lanjut dari kurikulum sebelumnya, yakni Kurikulum Berbasis Kompetensi (KBK). Pada dasarnya dua model kurikulum ini sama, yakni berorietasi pada suatu capaian kompetensi.

Pembelajaran bahasa Indonesia di dalam kurikulum ini di arahkan pada suatu kompetensi berbahasa baik secara lisan maupun tulis. Pembelajaran bahasa Indonesia diarahkan untuk meningkatkan kemampuan peserta didik untuk berkomunikasi dalam bahasa Indonesia dengan baik dan benar, baik secara lisan maupun tulisan, serta menumbuhkan apresiasi terhadap hasil karya kesastraan manusia Indonesia (BSNP, 2006). Dari uraian tersebut jelas ditunjukkan bahwa kemampuan peserta didik berkomunikasi dalam bahasa Indonesia menjadi tujuan pokok dari pembelajaran bahasa Indonesia di sekolah. Pendidikan tingkat dasar sampai tingkat tinggi, pembelajaran bahasanya sudah diarahkan pada kemampuan berkomunikasi secara praktis. 
Untuk mencapai suatu kemampuan berkomunikasi secara "baik", tidaklah mungkin dapat tercapai hanya dengan mempelajari bahasa secara struktural saja. Hal tersebut dikarenakan adanya banyak faktor di luar bahasa yang mempengaruhi proses berkomunikasi. Dalam hal ini, pendekatan pragmatik cukup membantu dalam pembelajaran bahasa yang berorientasi pada tindak komunikasi secara praktis.

Dalam kurikulum yang terbaru ini, dalam pembentukan arahan-arahannya juga sudah banyak melibatkan kajian pragmatik di dalamnya. Berbagai tuntutan kompetensi yang dihadirkan juga didasarkan pada tindak komunikasi (pragmatik). Standar kompetensi dan kompetensi dasar yang menjadi acuan dalam pembelajaran, sudah dirancang sedemikaian rupa untuk mengakomodasi tuntutan "siswa mampu berkomunikasi secara efektif efisien sesuai dengan etika yang berlaku, baik secara lisan maupun tulisan". Dari aspek mendengarkan

(menyimak), membaca, berbicara, dan menulis sudah didasarkan pada kebutuhan komunikasi; praktis. Dalam pembelajaran empat aspek tersebut, selalu akan diarahkan sampai pada kemampuan untuk menangkap wacana yang terdapat di luar aspek kebahasaan secara struktural. Dengan pemahaman yang baik terhadap hal-hal di luar bahasa, peserta didik diharapkan mamapu memaknai suatu bahasa dengan lebih baik, dan lebih jauhnya lagi peserta didik diharapkan mampu berkomunikasi dengan lebih baik pula.

Perencanaan yang seperti itu jelas harus didukung oleh seluruh elemen pendidikan. Ketika pada tataran konsep sudah baik, tetapi pada tataran praktis tidak dilakukan sesuai arahan, maka hasil yang dicapaipun tidak akan maksimal. Dengan kurikulum yang terbaru ini jelas guru sebagai salah satu elemen penting mempunyai keleluasaan dalam merancang proses pembelajaran yang disesuaikan dengan kebutuhan peserta didik. Setiap daerah akan mempunyai fenomena yang berbeda khususnya mengenai penggunaan bahasa. Namun yang perlu dijadikan pegangan oleh para guru yaitu adanya standar kompetensi dan kompetensi dasar yang harus dicapai. Selebihnya menjadi kebijakan pendidikan dalam mengakomidasi kebutuhan komunikasi yang disesuaikan dengan kebutuhan.

\section{Berbicara sebagai Suatu Keterampilan Berkomunikasi}

Pembelajaran bahasa Indonesia menurut kurikulum terbaru ( KTSP ) menitik beratkan pada terwujudnya siswa yang menguasai empat keterampilan berbahasa, yaitu keterampilan menyimak, berbicara, membaca dan menulis. Keempat keterampilan tersebut memiliki keterkaitan yang erat satu dengan yang lainnya.Walaupun demikian, masing-masing keterampilan tetap mempunyai wilayah dan kemandirian sendiri. Hal itu dapat terlihat dari gerakan-gerakan otak yang sedang bekerja. Ternyata bagian otak yang bekerja akan berbeda-beda apabila yang diuji itu sedang membaca, menyimak, berbicara atau berpikir tentang arti suatu kata (Cavendish, 1995: 62).

Berbicara merupakan wujud dari aktivitas lisan dalam komunikasi. Komunikasi yang efektif tidak hanya berkaitan dengan apa yang dikatakan seseorang, tetapi juga pada bagaimana ia mengatakannya. Hal ini menyangkut masalah bahasa dan non kebahasaan. Maidar dan Mukti (1987: 17-22) menjelaskan beberapa faktor sebagai penunjang keefektifan berbicara yaitu faktor kebahasaan dan faktor nonkebahasaan. Faktor kebahasaan meliputi: ketepatan ucapan; penempatan tekanan, nada, durasi yang sesuai; pilihan kata; dan ketepatan 
sasaran pembicaraan. Sedangkan faktor nonkebahasaan meliputi: sikap yang wajar,tenang,dan tidak kaku; pandangan pada lawan bicara; kesediaan menghargai pendapat orang lain; gerak-gerik dan mimik yang tepat; kenyaringan suara; kelancaran; penalaran; dan penguasaan topik.

Tindakan berbicara bukanlah suatu kegiatan berupa warisan yang diturunkan dari orang tua. Berbicara adalah suatu kegiatan keterampilan yang harus dipelajari dan berbicara digunakan untuk bermacam-macam fungsi sesuai dengan apa yang ingin disampaikan oleh penutur, misalnya : untuk menyatakan informasi faktual (mengidentifikasikan, melaporkan, menanyakan, mengoreksi), menyatakan sikap intelektual (menyatakan setuju atau tidak setuju, menyanggah, dan sebagainya), menyatakan sikap moral (meminta maaf, menyatakan penyesalan, penghargaan dan sebagainya), menyatakan perintah (mengajak, mengundang, memperingatkan, dan sebagainya).

Seperti yang dikatakan Tarigan bahwa berbicara itu lebih dari hanya sekedar pengucapan bunyi-bunyi atau kata-kata. Berbicara adalah suatu alat untuk mengkomunikasikan gagasan-gagasan yang disusun serta dikembangkan sesuai dengan kebutuhan-kebutuhan sang pendengar atau penyimak (Tarigan 1985: 15).

Dari uraian di atas dapat disimpulkan bahwa berbicara adalah kemampuan mengucapkan bunyi-bunyi artikulasi atau kata-kata untuk mengekspresikan, menyatakan serta menyampaikan pikiran, gagasan dan perasaan serta mengkomunikasikannya kepada orang lain. Pendengar menerima informasi melalui rangkaian nada, tekanan, dan penempatan penjedaan. Jika komunikasi berlangsung secara tatap muka proses berbicara ini dapat dibantu dengan mimik dan pantomimik pembicara.

\section{Pembelajaran Berbicara}

Pengertian berbicara dapat diartikan sebagai kemampuan mengucapkan bunyi-bunyi artikulasi atau kata-kata untuk mengekspresikan, menyatakan serta menyampaikan pikiran, gagasan dan perasaan serta mengkomunikasikannya kepada orang lain.

Berbicara adalah suatu alat untuk mengkomunikasikan gagasan-gagasan yang disususn serta dikembangkan sesuai dengan kebutuhan-kebutuhan sang pendengar atau penyimak (Tarigan, 1985: 15). Untuk itu berbicara sangatlah penting dan merupakan keterampilan berbahasa yang menunutut seseorang dapat menghasilkan sesuatu ungkapan atau ide dari buah pikiran dan dilontarkan dengan kat-kata. Untuk dapat memiliki keterampilan berbicara, orang tidak cukup hanya menguasai kosa kata saja tetapi perlu memiliki pengalaman dari membaca, pengalaman berbicara didepan orang banyak juga menguasai teknik sehingga apa yang disampaikan mudah dimengerti oleh lawan bicara.

Kemampuan berbicara dipandang sebagai keterampilan karena memperolehnya perlu dipraktekkan atau selalu digunakan. Hanya melalui praktik dan latihan-latihan berbicara secara memadai, maka kemampuan siswa dalam berbicara dapat meningkat (Mark D.Offiner 2001 : 2)

Berbicara merupakan aktifitas berbahasa kedua yang dilakukan manusia dalam kehidupan berbahasa yaitu setelah aktifitas mendengarkan. Berdasarkan bunyi-bunyi bahasa yang didengarkannya, kemudian manusia belajar mengucapkan dan akhirnya mampu berbicara. 
Berbicara adalah suatu alat untuk mengkomunikasikan gagasan-gagasan yang disusun serta dikembangkan sesuai dengan kebutuhan-kebutuhan sang pendengar atau penyimak. Lebih jauh dikatakan berbicara merupakan instrument yang mengungkapkan kepada penyimak hampir-hampir secara langsung apakah pembicara memahami atau tidak, baik bahasa pembicaranya maupun penyimaknya. Jadi berbicara merupakan sebuah sarana untuk menuangkan gagasan atau ide kepada pendengar.

Pembelajaran berbicara tidak dapat dipisahkan dengan pembelajaran bahasa Indonesia karena sesuai dengan kedudukan dan fungsinya pada dasarnya tujuan pembelajaran bahasa Indonesia adalah agar siswa mampu menggunakan bahasa Indonesia dengan baik dan benar dalam berbagai peristiwa komunikasi, baik secara lisan maupun tulisan.

Pembelajaran berbicara harus dilaksanakan dengan menciptakan situasi belajar yang mungkinkan siswa dapat mengembangkan berbicara semaksimal mungkin. Kegiatan belajar mengajar yang dilaksanakan harus senantiasa memberikan kesempatan siswa untuk berlatih berbicara karena keterampilan berbicara hanya dapat dikuasai dengan baik apabila pembicara diberi kesempatan berlatih sebanyak-banyaknya.

Beberapa prinsip yang diterapkan dalam pembelajaran berbicara adalah:

a) Memberikan kesempatan berbicara sebanyak-banyaknya. Hal ini perlu latihan praktik yang dilaksanakan secara teratur dan terarah. Jadi, siswa tidak hanya mengetahui teori berbicara, melainkan mereka berlatih menerapkan teori tersebut ke dalam kondisi sealamiah mungkin.

b) Latihan berbicara dijadikan bagian yang integral dari program pembelajaran sehari-hari. Karena itu perlu adanya koordinasi antara guru bahasa Indonesia dengan guru mata pelajaran lain dalam hal memberi kesempatan berlatih berbicara kepada para siswa sehingga siswa secara aktif berlatih berbicara dalam suatu komunikasi sewajarnya.

c) Dapat menumbuhkan kepercayaan diri. Salah satu hambatan yang dihadapi seorang siswa adalah kurangnya rasa percaya diri. Latihan berbicara yang dilaksanakan secara teratur sangat berguna bagi pembinaan rasa percaya diri kepada para siswa. Upaya meningkatkan rasa percaya diri pada waktu berbicara dengan cara : (1) Berusaha menguasai apa yang akan disampaikan kepada para pendengar; (2) Menyusun masalah yang akan disampaikan secara sistematis sehingga menjadi suatu yang menarik bagi lawan bicaranya; (3) Meyakinkan diri bahwa apa yang akan disampaikan itu adalah hal yang benar dan penting serta bermanfaat bagi pendengar. Keyakinan ini akan menjadikan pembicara lebih berani tampil di depan pendengar sehingga rasa percaya diri akan lebih mantap; (4) Berpikir secara terbuka, santai, serta memandang pendengar sebagai pihak yang tidak lebih tahu tentang hal yang akan disampaikan.. Justru pendengar perlu diberi tahu tentang apa yang akan dibicarakannya itu ( Depdiknas, 2004:81-82)

d) Guru dalam memilih dan menentukan materi pembelajaran berbicara seharusnya menyesuaikan dengan butir-butir materi yang digariskan dalam kurikulum. Selain itu, pemilihan materi seharusnya disesuaikan pula dengan tingkat kelas siswa serta situasi dan kondisi yang melingkupi. Semua materi berbicara di atas dipadukan dengan keterampilan berbahasa lainnya yaitu menyimak, membaca, dan menulis. 


\section{Aspek-aspek yang Dinilai dalam Kemampuan Berbicara}

Untuk dapat menjadi pembicara yang baik, seorang pembicara selain menguasai masalah yang dibicarakan juga harus memperlihatkan keberanian dan kegairahan. Pembicara harus berbicara dengan jelas dan tepat. Dalam hal ini ada beberapa aspek yang harus diperhatikan oleh pembicara untuk keefektifan dalam berbicara, yaitu aspek kebahasaan dan aspek non kebahasaan.

1. Aspek kebahasaan

a) Ketepatan ucapan: Artinya pembicara harus membiasakan diri mengucapkan bunyi-bunyi bahasa secara tepat.

b) Penempatan tekanan yang dalam bahasa Indonesia ini sangat penting.

c) Pilihan kata (diksi), meskipun tidak mengubah arti hendaknya tepat, jelas dan bervariasi.

d) Ketepatan sasaran pembicaraan , yaitu dengan menggunakan kalimat efektif.

2. Aspek Non Kebahasaan

Dalam pembicaraan yang bersifat formal aspek non kebahasaan sangat diperlukan, karena penguasaan aspek non kebahasaan akan mempermudah penerapan aspek kebahasaan. Adapun yang termasuk aspek non kebahasaan adalah:

1) Sikap yang wajar, tenang dan tidak kaku

2) Pandangan mata yang terarah kepada lawan bicara

Tujuan akhir pembelajaran bahasa adalah mengembangkan kemampuan komunikatif yakni kemampuan seseorang untuk tidak hanya menggunakan kaidah-kaidah bahasa agar dia dapat menyusun kalimat-kalimat secara gramatikal tetapi juga dapat menggunakan kalimat-kalimat itu untuk berkomunikasi secara kontekstual.

Ada lima ( 5 ) unsur pembentuk kemampuan komunikatif yaitu :

a. Penguasaan gramatikal, yaitu penguasaan terhadap kaidah-kaidah bahasa yang membuat orang itu mampu membedakan mana kalimat yang benar dan mana yang salah.

b. Kemampuan sosiolinguistik, yaitu kemampuan untuk menggunakan bahasa secara tepat sesuai dengan konteksnya.

c. Kemampuan psikolinguistik, yaitu kemampuan menggunakan bahasa sesuai dengan psikis.

d. Kemampuan wacana, yaitu kemampuan menggunakan bahasa dalam wacana atau konteks tertentu.

e. Kemampuan strategis, yaitu kemampuan seseorang untuk membuat agar komunikasi berjalan dengan lancar atau komunikasi tidak macet.

Perbedaan pedoman untuk penilaian kegiatan berbicara berdasarkan faktor penunjang, seperti terlihat pada tabel berikut ini:

\section{Tabel 3. Perbedaan Pedoman Penilaian Kegiatan Berbicara Berdasarkan Faktor Penunjang}

\begin{tabular}{ll}
\hline \multicolumn{1}{c}{ Faktor kebahasaan } & \multicolumn{1}{c}{ Faktor Non Kebahasaan } \\
\hline 1. pengungkapan vokal & 1. keberanian dan semangat, \\
2. pengungkapan konsonan & 2. kelancaran, \\
3. penetapan tekanan & 3. kenyaringan suara, \\
\hline
\end{tabular}




\begin{tabular}{ll}
\hline \multicolumn{1}{c}{ Faktor kebahasaan } & \multicolumn{1}{c}{ Faktor Non Kebahasaan } \\
\hline 4. penempatan persendian & 4. pandangan mata, \\
5. penggunaan nada irama & 5. gerak-gerik dan mimik, \\
6. pilihan kata & 6. keterbukaan, \\
7. variasi kata & 7. penalaran, \\
8. tata tekanan & 8. penguasaan topik \\
9. struktur kalimat & 9. keberanian dan semangat, \\
10. ragam kalimat & 10. kelancaran, \\
\hline
\end{tabular}

Jadi kemampuan berbicara pada hakekatnya adalah kesanggupan siswa dalam mengungkaapkan pikiran, pendapat, gagasan dan perasaan secara lisan kepada orang lain yang diindikatori melalui kemampuan mereka dalam menyampaikan ide, yaitu (1) sesuai dengan isinya, (2) dengan penggunaan struktur kalimat yang tepat, (3) dengan ekspresi yang tepat, (4) pilihan kata atau diksi yang tepat, (5) suara yang jelas, (6) pelafalan yang tepat.

\section{Implemetnasi Pendekatan Pragmatik dalam Pembelajaran Keterampilan Berbicara}

Agaknya tidak terlalu sulit guru menerapkan pragmatik dalam keterampilan berbicara karena peserta didik bisaanya sangat suka berbicara. Maksudnya pada umumnya peserta didik senang kalau proses pembelajaran di kelas tersebut aktif. Karena dengan begitu mereka akan bersemangat dalam mengikuti pembelajaran yang akan diadakan. Penerapan pragmatik dalam keterampilan berbicara misalnya pembelajaran pada tingkat SMA kelas $\mathrm{X}$ semester 1 . Aspeknya adalah berbicara dengan standar kompetensinya yaitu "mengungkapkan pikiran, perasaan, dan informasi melalui kegiatan berkenalan, diskusi, dan bercerita". Kompetensi dasarnya adalah "memperkenalkan diri dan orang lain di dalam forum resmi dengan intonasi yang tepat".

Dalam rencana pembelajaranya. Peserta didik diarahakan untuk dapat memperkenalkan diri dan orang lain dalam suatu forum yang resmi. Dalam hal ini guru memberi arahan materi sebelum peserta didik mempraktikkan kompetensi tersebut. Dalam arahanya guru menyampaikan materi bahwa dalam memperkenalkan diri maupun orang lain kita harus memahami situasi yang ada dalam forum itu. Dari materi ini jelaslah bahwa unsur-unsur di luar bahasa mulai dperhatikan, dengan kata lain kemampuan pragmatik mulai diperkenalkan pada peserta didik. Lebih lanjut guru menerangkan hal-hal yang perlu diperhatikan dalam berbicara (memperkenalkan diri) di dalam forum resmi, seperti dalam forum itu dihadiri siapa saja (peserta didik berhadapan dengan siapa), orang yang diperkenalkan itu siapa, status atau kedudukannya dalam forum menjadi apa, situasi yang dihadapi seperti apa, tujuannya apa, dan berbagai hal yang lain yang perlu diperhatikan (mengacu pada kajian pragmatik).

Selanjutnya guru mencoba menciptakan suatu situasi atau kondisi pembelajaran sedemikian rupa, sehingga peserta didik mendapat kesempatan untuk menunjukkan kompetensi yang dimilikinya dalam suatu situasi yang diciptakan tersebut. Dengan memberikan peran-peran tertentu pada beberpa orang, peserta didik dihadapkan pada suatu situasi seperti yang diharapkan untuk belajar menghadapi situasi tertentu. 
Dari pembelajaran yang dilakukan akan dapat terlihat, bagaimana komunikasi yang terjadi, apakah peserta didik sudah mampu berkomunikasi dengan tepat pada suatu situasi yang diciptakan tersebut. Ketercapaian tersebut dapat dilihat dari bagaimana sikap yang ditunjukkan, bagaimana pilihan kata yang digunakan, tujuan berkomunikasinya tercapai atau tidak, dan sebagainya.

Dengan proses pembelajarn yang seperti itu diharapkan, peserta didik paling tidak mendapatkan pengalaman belajar. Lebih jauh lagi peserta didik mengetahui berbagai hal yang perlu diperhatikan dalam proses berkomunikasi secara praktis. Pada akhirnya peserta didik akan mendapat bekal untuk berkomunikasi dlaam masyarakat, paling tidak yang berhubungan dengan materi yang diajarkan.

\section{Simpulan}

Pembelajaran bahasa membawa kita pada suatu pemahaman tentang pentingnya pendekatan pragmatik dalam pembelajaran keterampilan berbicara. Dalam pembelajaran bahasa khususnya pada aspek pembelajaran berbicara, ketercapaian suatu kompetensi berbahasa yang tepat tidaklah hanya dengan mempelajari bahasa secara struktural, tetapi juga harus didukung oleh suatu pembelajaran tentang aspek-aspek yang ada di luar bahasa yang seringkali berpengaruh dalam proses komunikasi. Dengan pendekatan pragmatik pula, peserta didik akan lebih didekatkan dengan kondisi praktis berbicara baik secara lisan maupun tulisan. Selain itu, mengingatkan bahwa Indonesia memiliki banyak sekali budaya termasuk di dalamnya bahasa, dengan pendekatan pragmatis dalam pembelajaran bahasa, sedikit banyak kendala yang muncul akan terakomodir. Terlebih lagi didukung dengan suatu kurikulum yang sebagian besar kebijakannya diserahkan pada masing-masing tingkat satuan pendidikan, pembelajaran (khususnya bahasa) yang muncul akan lebih mampu mengakomidasi kebutuhan peserta didik.

Dengan demikian, pembelajaran keterampilan berbicara dengan pendekatan pragmatik ini sangat efektif dalam menciptakan pembelajaran yang aktif terutama dalam meningkatkan kemampuan berbicara siswa di dalam kelas maupun diluar kelas. 


\section{DAFTAR PUSTAKA}

Bambang Kuswanti Purwo. 1990. Pragmatik dan Pengajaran Bahasa: Menyibak Kurikulum1984. Yogyakarta: Kanisius.

BSNP. 2006. Standar Kompetensi dan Kompetensi Dasar: Mata Pelajaran Bahasa Indonesia untuk SMA/SMK. Jakarta: Depdiknas.

Budinuryanto Yohanes. (2006). Pendekatan Pragmatik. Di akses pada 2 Juni 2012, dari http://digilib.upi.edu/pasca/available/etd-1127106-110028/.

Chaniago, Sam Mukhtar, Mukti U.S., Maidar Arsyad. 1997. Pragmatik. Jakarta: Universitas Terbuka.

Edi Subroto. 2011. Pengantar Studi Semantik dan Pragmatik. Surakarta: Cakrawala Media

Henry GunturTarigan. 2008. Berbicara sebagai Suatu Keterampilan Berbahasa. Bandung: Angkasa.

Maidar G. Arsjad dan Mukti U.S. 1988. Pembinaan Kemampuan Berbicara Bahasa Indonesia. Jakarta: Erlangga.

Nurhadi. 1995. Tata Bahasa Pendidikan: Landasan dalam Penyusunan Buku Pelajaran Bahasa. Semarang: IKIP Semarang Press.

P.W.J Nababan. 1987. Ilmu Pragmatik (Teori dan Penerapannya). Jakarta: Depdiknas.

Yayuk Eny. (2004).Pengajaran Bahasa di Sekolah.Di akses pada 2 Juni 2012, dari http://lib.balaibahasa.org/viewdetail.php?id=1163. 